\title{
SOME INTERACTIONS BETWEEN PILEATED WOODPECKERS AND NORTHERN HAWK OWLS
}

ROBERT W. NERO, Wildlife Branch, Box 24 - 200 Saulteaux Crescent, Winnipeg, MB R3J 3W3, and HERBERT W.R. COPLAND, Manitoba Museum of Man and Nature, 190 Rupert Avenue, Winnipeg, MB R3B ON2

In the winter of 1991-92, Northern Hawk Owls appeared in large numbers in southern Manitoba. Between 1 December 1991 and 11 April 1992, we captured and banded 76; another 60 were banded by Jim and Patsy Duncan. We found as many as 23 Hawk Owls in one day (29 February 1992) and were so busy that there was little time to observe their behaviour. Two brief episodes involving Pileated Woodpeckers, however, caught our attention.

On 9 February 1992, in mid-morning on the Fort Alexander Indian Reserve (Sagkeeng First Nation), on the north side of the Winnipeg River, we found an owl perched on the topmost branch of a tree about $150 \mathrm{~m}$ from the road. The tree was at the far end of a row of aspens along a small ravine. Since Hawk Owls sometimes will respond to a lure from as far away as they can be identified, we proceeded to try and coax this bird to come to us. After several minutes, we saw a Pileated Woodpecker fly about $200 \mathrm{~m}$ from a wood on the opposite side of the road straight to the trunk of the tree and some distance below the owl. At once, the owl dropped off its perch and landed near the woodpecker, whereupon the latter flew to another position on the same tree. Twice more the owl darted at the woodpecker, which each time changed position on the tree. Finally, the woodpecker flew off in the direction from which it had first come, leaving the owl now perched low and close to the trunk of the tree. After several minutes, the owl returned to its original treetop position. Upon capturing the owl, we determined it to be a juvenile.

In the winter of 1993-94, Hawk Owls were scarce in southern Manitoba; only five records came to our attention. A week after banding another juvenile owl at $\mathrm{Ft}$. Alexander I.R. (just $9 \mathrm{~km}$ west of the above 1992 site), we saw another encounter with a Pileated Woodpecker. This was at noon on 5 March 1994. We were parked on the side of the road watching the owl, which was on a hydro pole. The owl flew across the road to a large spruce tree in front of a house, then dropped down and captured what we presumed was a vole; with the melting snow at this time, vole signs were conspicuous. The owl flew with its prey across the road and straight back a few hundred metres to the edge of a wood, returning almost at once to perch on a hydro pole. Thinking that the owl might have visited a nest site, we walked back to the trees to check. While we were looking at an old woodpecker nest hole in a dead aspen, we heard a faint chirping sound, 


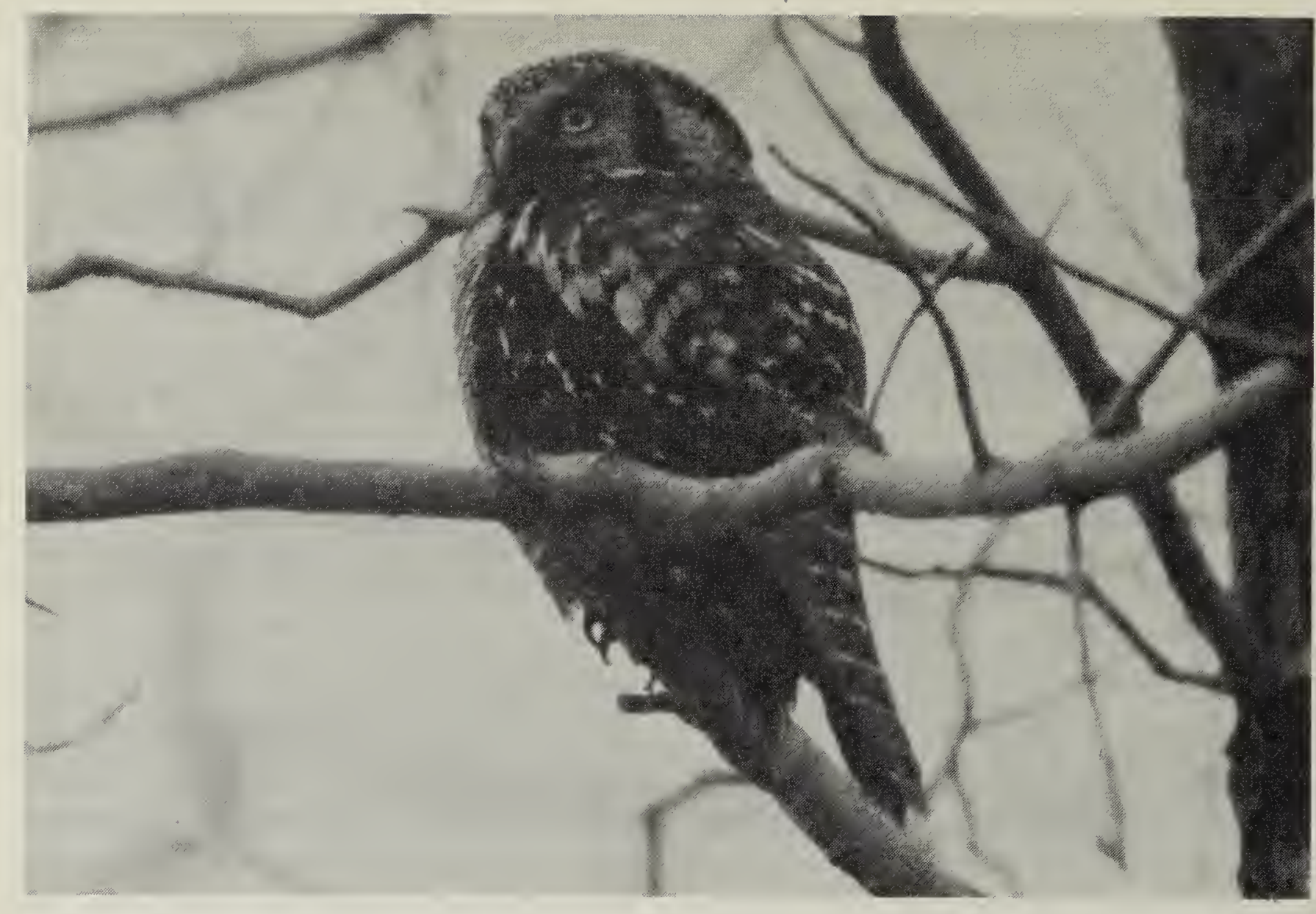

Hawk OwI

Wayne Lynch

remindful of the scolding notes of an American Robin. Shortly, we realized that the sound was coming from behind us. We turned to see that, back at the road, the Hawk Owl, still on top of a hydro pole, was being harassed by a Pileated Woodpecker.

As we hurried back for a closer look at the action, we saw the woodpecker fly around the owl, about 5-6 $\mathrm{m}$ away and at the same level. Twice, the owl dived off its perch and flapped about in a circular manner, apparently aroused by its assailant, then flew to the next pole. Several times we could hear the excited chirping sound, but at our distance we couldn't be sure which bird was giving it. It was loudest when the woodpecker was circling the owl, and it sounded a little like a Northern Flicker's call. Bent notes that when the Pileated Woodpecker "is in flight a slowly uttered puck, puck may sometimes be heard." ${ }^{2}$ Whether that could be the sound we heard is uncertain, but, according to the Dun- cans, alarm calls of Northern Hawk Owls are much different. ${ }^{5}$ When we were close enough to see that the woodpecker's crest was raised, the woodpecker once more circled about the owl, which had flown to the top of a third pole. The woodpecker then flew across the road to perch close to the top of a pole near the house (where earlier the owl had captured prey) before flying off into nearby woods.

It is possible that the woodpecker had laid some claim to a large mass of flesh and fat that we noticed on a bird feeder in the yard of that house. This could be one reason for the woodpecker's obvious belligerence. Of course, any owl is likely to be mobbed by other birds. A Hawk Owl that over-wintered in Winnipeg (1993-94) occasionally attracted the attention of Black-capped Chickadees, Common Redpolls and a Hairy Woodpecker. ${ }^{6}$ The Northern Hawk Owl is capable of taking even large avian prey, for example, ptarmigan 


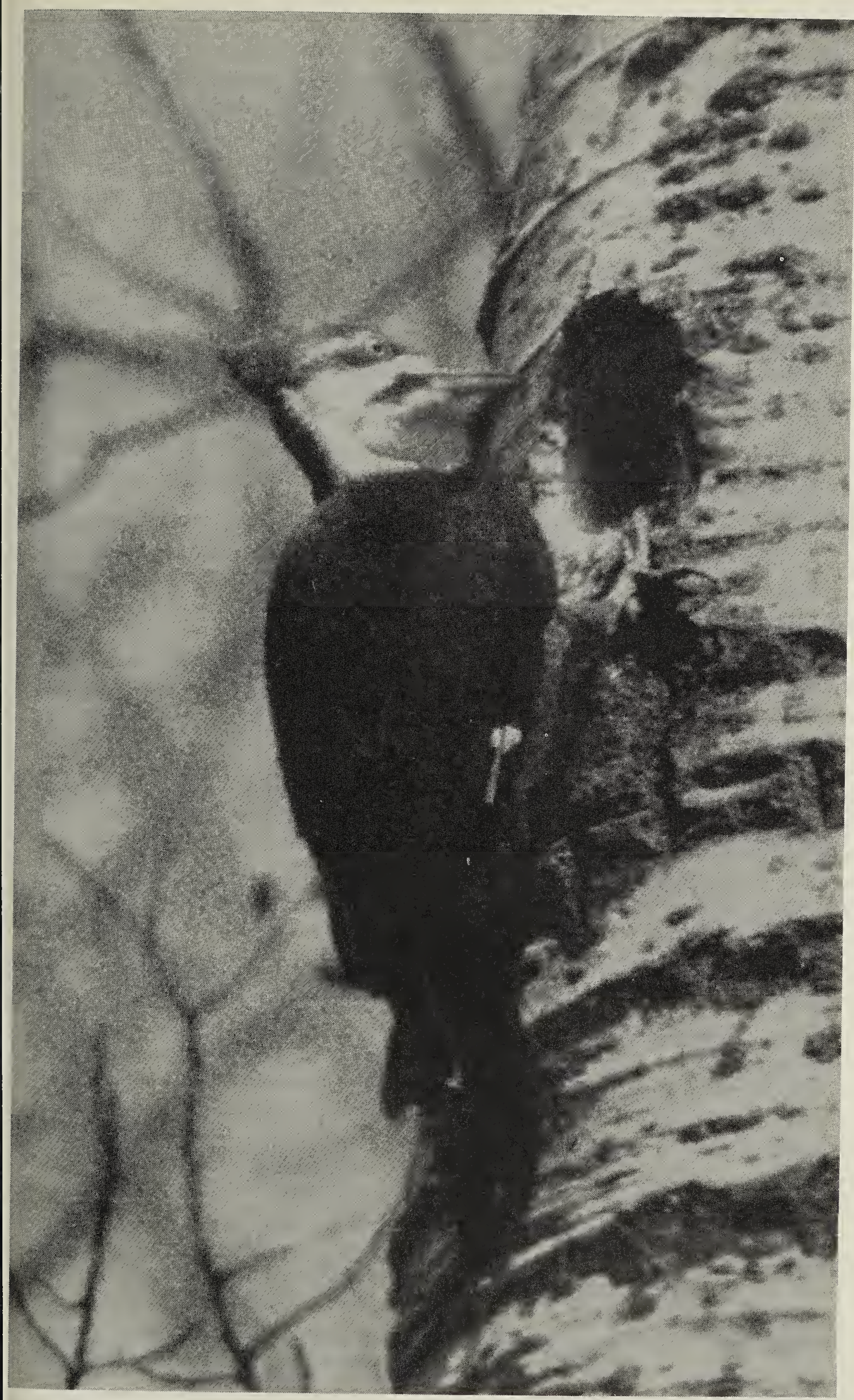


and Spruce Grouse. ${ }^{4}$ Thus, the boldness of birds that harass this species is perhaps surprising.

After a juvenile Hawk Owl was banded and released by the Duncans south of The Pas, 10 March 1992, it was mobbed by four Gray Jays, then a Pileated Woodpecker flew in, landing $2 \mathrm{~m}$ below the owl. With head plumage erected, the woodpecker climbed upwards within centimetres of the unresponsive owl before flying away. And in late winter 1991-92 at McMunn, the Duncans noted that when a Hawk Owl flew to a large, isolated Manitoba maple, a Pileated Woodpecker flew in, head feathers erect, "uttering loud raucous calls." The woodpecker, which appeared to be "intensely agitated," made several passes, coming within .3 to $.6 \mathrm{~m}$ of the seemingly unconcerned owl. These observations suggest that Hawk Owls are not much bothered by presumed threat displays given by Pileated Woodpeckers. In contrast, on 7 March 1992, on PTH 8 west of the causeway to Hecla Island, we saw a Hawk Owl give an aggressive response to a Common Raven that landed on the top of a tree about $50 \mathrm{~m}$ away. The owl fanned its tail and squawked loudly.

Perhaps the Pileated Woodpeckers in the above observations were acting aggressively towards a potential nest site usurper. Hawk Owls are known to use woodpecker cavities for nesting and roosting, especially those of the Pileated Woodpecker, which makes the largest holes. ${ }^{1,2,7}$ Voous, in a substantial report on the Holarctic Northern Hawk Owl, notes: "Its interspecific relations with ... woodpeckers which provide the owl with nest holes, are subjects requiring detailed study, as is its life in winter." In Nebraska, on 26 March 1991, a female Pileated Woodpecker came out of hiding in response to a taped call of an Eastern Screech Owl, another cavity nester. ${ }^{8}$. Wright notes: "While I urge caution in the use of tapes of any kind, our unexpected success with this technique may be of use to other birders in search of Nebraska's most elusive woodpecker." ${ }^{8}$ Bolles, ${ }^{3}$ quoted by Bent, tells how a Pileated Woodpecker, upon seeing a tame Barred Owl (another hole nester) outdoors, began vigorously flying at the owl while giving a "shrieking cackle," making the owl "unhappy for some time by his discordant cries and frequent flights and counter flights."

Acknowledgements. We are grateful to James R. Duncan and Patricia A. Duncan for allowing us the use of their observations, and for their comments on this report. Paul A. Johnsgard kindly forwarded a copy of the Wright article. For typing assistance, we thank Gordon G. Graham.

1. BENT, A.C. 1938. Life histories of North American birds of prey. Part 2. U.S. Natl. Mus. Bull. 170. Dover reprint 1961.

2. - 1939. Life histories of North American woodpeckers. U.S. Natl. Mus. Bull. 174. Dover reprint 1964.

3. BOLLES, F. 1890. Barred Owls in captivity. Auk 7: 101-114.

4. KILIAAN, H.P.L. 1989. A Hawk OwISpruce Grouse encounter in the Northwest Territories. Blue Jay 47: 213-214.

5. LANE, P.A. and J.R. DUNCAN. 1987. Observations of Northern Hawk-Owls in Roseau County. The Loon 59: 165-174.

6. NERO, R.W. 1995. Notes on a wintering Northern Hawk Owl in Manitoba. Blue Jay 53: 205-214.

7. VOOUS, K.H. 1988. Owls of the northern hemisphere. Collins, London. 320 pp.

8. WRIGHT, R. 1991. Pileated Wood. pecker responds to owl tape Nebraska Bird Review 59 (3): 98-99. 